\title{
Studies on Preparation of Tempeh-like Product from green Peas (Pisum sativum)
}

\author{
A. Sayed Rizwan ${ }^{1}$, U.G. Miniyar ${ }^{2}$ and B.K. Sakhale ${ }^{3^{*}}$ \\ ${ }^{1}$ Department of Microbiology, Sir Sayyed College, Aurangabad, \\ ${ }^{2}$ Department of Food Production, Government College, Aurangabad, \\ ${ }^{3}$ University Department of Chemical Technology, Dr. Babasaheb Ambedkar Marathwada \\ University, Aurangabad-431004(M.S.), India \\ "Email: bksakhale@gmail.com
}

\begin{abstract}
The Tempeh like fermented product was prepared from the green peas by using the various strains of Rhizopus species and it was subjected to analysis of physico-chemical, nutritional characteristics and overall quality. The study revealed that protein; free amino acids, reducing sugars and ascorbic acid contents were increased considerably in fermented products than in the unfermented product. However sucrose and phytate contents were also reduced respectively. The product made from green peas was also compared with soy tempeh. It was observed that the product made from green peas was very similar in appearance, texture and nutrients as that of soybean tempeh.
\end{abstract}

Key words: Fermentation, green peas, nutrition, quality, texture, tempeh.

Paper cited: Sayed Rizwan, A., Miniyar, U.G. and Sakhale, B.K. (2016). Studies on Preparation of Tempeh-like Product from green Peas (Pisum sativum). South Asian Journal of Food Technology and Environment, 2(2): 366-371.

\section{Introduction}

Pulses are important foodstuffs in many parts of world, when the proteins from animal sources are less readily available. Pulses are used in Asia to prepare human food much more than in any other continent. The Orientals learns centuries ago the techniques of hydrolyzing proteins and starches by enzymes produced by moulds (Padamja and George, 2004). Pulses contain higher protein than cereals. However, legume proteins have low biological value compared to animal proteins due to deficiency of Sulphur containing amino acids and many antinutritional factors. Green peas (Pisum sativum) are one of the most important pulses in Indian diet (especially North India). It is also consumed as vegetable in raw state.

Protein malnutrition is one of the major problems in developing countries like India. Children are protein malnourished. There is need to develop protein rich food at low cost to poorer sections of society in developing countries. The efforts are being made in making protein rich food.

Tempeh, a protein rich food is made by fermenting soybean with mould Rhizopus oligosporus. Tempeh is a fermented product made from soybeans that have been soaked and cooked to soften them (Astuti et al., 2000). It is popular in Indonesia, Japan and other Oriental countries. In Indonesia freshly prepared tempeh is sliced and sun dried. Dehydrated tempeh which had good keeping quality for many months has been made (Steinkraus et al., 1965). Tempeh has a solid cake bounded by dense white, cottony mycelia. It has pleasant flavour when fried in vegetable oil and it has nutritive value. It is used as substitute for animal products in what in the west is critically called as "mock" burger or sandwiches. It also has the advantages of containing vitamin $B_{12}$ which is a by-product of the fermentation process.

Tempeh like products can be prepared from pulses like green peas, chick peas, cow peas, local beans, etc. with same nutritional 
significance as that of tempeh. Cereals like wheat, oats, rye, barley, rice and combination with or without soybeans have also been used in tempeh manufacture (Wang et al., 1969). Many different substrates can be used to produce tempeh (Table 1). Some substrates can only be processed to obtain high quality tempeh by combining them with soybeans (Wang et al., 1969; Mugula, 1992; Shurtleff and Aoyagi, 2001).

Table 1: Production of Tempeh from various food stuffs

\begin{tabular}{|c|c|c|}
\hline Raw materials & Organisms & References \\
\hline $\begin{array}{l}\text { Legumes } \\
\text { Soybeans (Glycine max) } \\
\text { Black gram (Phaseolus mungo) }\end{array}$ & $\begin{array}{l}R . \text { oligosporus } \\
R . \text { oligosporus }\end{array}$ & $\begin{array}{l}\text { Varzakas (1998) } \\
\text { Jha and Verma (1980) }\end{array}$ \\
\hline $\begin{array}{l}\text { Cereals } \\
\text { Barley (Hordeum vulgare) } \\
\text { Wheat (Triticum vulgare) } \\
\text { Sprouted Broken rice }\end{array}$ & $\begin{array}{l}\text { R. oligosporu } \\
\text { R. oligosporu } \\
\text { R. oligosporu }\end{array}$ & $\begin{array}{l}\text { Nout and Rombouts (1990), Hachmeister } \\
\text { and Fung (1993), Berg et al., (2001) } \\
\text { Hesseltine and Wang (1980), Nout and } \\
\text { Rombouts (1990), Hachmeister and } \\
\text { Fung(1993) } \\
\text { Babu et al., (2009) }\end{array}$ \\
\hline $\begin{array}{l}\text { Mixture of legumes with non- } \\
\text { legumes } \\
\text { Sesame and soybean } \\
\text { Maize and soybean }\end{array}$ & $\begin{array}{l}R . \text { oligosporus } \\
R . \text { oligosporus }\end{array}$ & $\begin{array}{l}\text { Shurtleff and Aoyagi (2001) } \\
\text { Nout and Kiers (2005) }\end{array}$ \\
\hline $\begin{array}{l}\text { Press cake (by-products) } \\
\text { Soybean residue from soymilk } \\
\text { preparation or okara }\end{array}$ & R. oligosporus & $\begin{array}{l}\text { Ko Swan and Hesseltine (1979), Matsuo } \\
\text { (1990) }\end{array}$ \\
\hline $\begin{array}{l}\text { Groundnut press cake } \\
\text { (Arachis hypogaea) }\end{array}$ & R. oligosporus & Gandjar (1981) \\
\hline
\end{tabular}

\section{Materials and Methods}

Tempeh was prepared from green peas (Pisum sativum) by using mould cultures of Rhizopus species. These cultures were Rhizopus stolonifer, Rhizopus formosaensis, Rhizopus oligosporus. These cultures were obtained from National Chemical, Laboratory, Pune, Maharashtra. These cultures were activated on potato dextrose agar medium by frequent sub culturing and $48 \mathrm{hr}$ old cultures were used for fermentation. The method involved in tempeh production differs from each other and researchers reported overall production methods with the process based on various factors (Hachmeister and Fung, 1993; Nout and Kiers, 2005).
The beans were cleaned and sound beans were used for tempeh preparation. Around $200 \mathrm{~g}$ of green peas was taken, washed with clean water and then drained the excess water. Peas was soaked in acidified water $(0.25 \%$ glacial acetic acid solution) with the proportion of 1:3 for $14 \mathrm{hr}$, dehulled by hand and cooked in pressure cooker in soaking water at 15 psi pressure for $5 \mathrm{~min}$. Soybeans were cooked in boiling water for $45 \mathrm{~min}$ and then drained to remove excess water. It was then dewatered by spreading them on clean filter paper and allowed to cool at room temperature. These beans were compactly packed in sterilized Petri plates inoculated with the species of Rhizopus stolonifer, Rhizopus oligosporus, and Rhizopus formosaensis in triplicates and incubated at $31^{\circ}$ 
$\mathrm{C}$ for $48 \mathrm{hrs}$ and at high humidity. In addition to oxygen, the mould grows better in high humidity levels (75- 78\%) (Babu et al., 2009). The inoculums used were $48 \mathrm{hr}$ old; it was grown on $10 \mathrm{ml}$ potato dextrose medium. The mycelia growth was dispersed in $12 \mathrm{ml}$ sterilized water in order to have uniform distribution of inoculums. The entire fermented product obtained was frozen and freeze dried. The freeze dried samples were then used for chemical analysis. The various chemical parameters like protein, soluble nitrogen, free amino acids, phytate, reducing sugar, sucrose, Vitamin C content etc. were estimated as per standard methods of AOAC (2000).

\section{Results and Discussion}

The nutritional analysis of tempeh and tempeh like product prepared from green peas and soybeans were analyzed chemically with respect to protein, soluble nitrogen, vitamin-C, free amino acids, phytate and sucrose content. The analysis was carried out for raw material and tempeh like product prepared from green peas and soybeans by using three different fungal cultures.
Protein g/100gm, soluble nitrogen $\mathrm{g} / 100 \mathrm{gm}$ and free amino acids $\mathrm{mg} / 100 \mathrm{gm}$ of unfermented and fermented products were tabulated in Table 2. The data presented in Table 2 indicated that the protein content of tempeh prepared from green peas and soybeans were reduced in comparison with raw materials used for the same. It may due to the higher protease activity of the fungal cultures used. The highest reduction in protein content was observed in tempeh prepared by using the starter culture of Rhizopus formanseansis and lowest in the tempeh of Rhizopus oligosporus. Stenkraus et al., (1961) reported that the total protein in tempeh and cooked unfermented soybean was approximately same. Murata et al., (1967) were stated that no large difference in protein and ash content between a tempeh and unfermented soybeans. Nowak and Szebiotko (1992) were noted that fermentation led to significant decrease in protein nitrogen and increase in ammonical- nitrogen and aminonitrogen in soybean and especially in pea when culture of mould used as Rhizopus oligosporus 2770 to produce three kinds of soybean and one kind of pea Tempeh.

Table 2: Nutritional contents of fermented and unfermented peas and soybeans

\begin{tabular}{|l|c|c|c|c|c|c|c|c|}
\hline \multirow{2}{*}{ Nutrients } & \multicolumn{2}{|c|}{ Unfermented } & \multicolumn{6}{c|}{ Fermented (Tempeh) } \\
\cline { 2 - 9 } & Peas & Soybeans & \multicolumn{3}{|c|}{ Peas } & \multicolumn{3}{c|}{ Soybeans } \\
\cline { 4 - 9 } & & & $\mathbf{R}_{\mathbf{1}}$ & $\mathbf{R}_{\mathbf{2}}$ & $\mathbf{R}_{\mathbf{3}}$ & $\mathbf{R}_{\mathbf{1}}$ & $\mathbf{R}_{\mathbf{2}}$ & $\mathbf{R}_{\mathbf{3}}$ \\
\hline Protein (\%) & 19.78 & 44.35 & 17.68 & 17.50 & 17.75 & 39.66 & 39.95 & 41.12 \\
\hline Sol. N $(\%)$ & 0.39 & 0.57 & 1.008 & 1.14 & 0.99 & 1.33 & 1.34 & 1.24 \\
\hline $\begin{array}{l}\text { FAA } \\
\text { (mg/100gm) }\end{array}$ & 108 & 232 & 610 & 540 & 440 & 1240 & 1150 & 1420 \\
\hline $\begin{array}{l}\text { Ascorbic acid } \\
\text { (mg/100gm) }\end{array}$ & 0.72 & 4.36 & 14.5 & 10.9 & 10.9 & 16.3 & 16.3 & 14.3 \\
\hline $\begin{array}{l}\text { Phytate } \\
\text { (g/100g) }\end{array}$ & 0.13 & 0.21 & 0.045 & 0.051 & 0.045 & 0.088 & 0.090 & 0.094 \\
\hline $\begin{array}{l}\text { Reducing } \\
\text { sugars } \\
\text { (g/100g) }\end{array}$ & 3.8 & 0.5 & 4.4 & 5.8 & 4.4 & 0.92 & 0.87 & 0.84 \\
\hline $\begin{array}{l}\text { Sucrose } \\
\text { (g/100g) }\end{array}$ & 1.33 & 0.14 & 1.14 & 0.93 & 1.10 & 0.1 & 0.114 & 0.12 \\
\hline
\end{tabular}

(Legends: Sol. $\mathrm{N}_{2}$ - Soluble nitrogen, FAA- Free amino acid)

(Legends: $\mathrm{R}_{1}$-Rhizopus oligosporus, $\mathrm{R}_{2}$-Rhizopus stolonifer, $\mathrm{R}_{3}$-Rhizopus formosaensis)

The percent soluble nitrogen was increased approximately 2 times from 0.39 to
$1.14 \%$ in green peas tempeh inoculated by $R$. stolonifer whereas around 0.70 times increased 
in the same tempeh inoculated by $R$. formoseansis. However, in soybeans it was observed exactly one and half times greater than unfermented. It was also noted that soluble nitrogen was more in tempeh fermented with $R$. oligosporus than other mould inoculums. $R$. oligosporus had strongest protein activity (Shurtleff and Aoyagi, 2001) whereas the total nitrogen content of cooked beans did not change with fermentation, the soluble nitrogen increased from 0.5 to $2.0 \%$ (Hasseltine, 1965). Steinkraus et al. (1961) and Murata et al. (1967) reported that the soluble nitrogen increased from 0.5 to $2.5 \%$ that is approximately 5 times as that of original.

It was found that the amount of free amino acid was increased around 5 times in peas and 6 times in soybeans. Similar result was also noted by Stillings and Hackler (1965) except that lysine and methionine were decreased and rest the amount of free amino acids were increased of all free amino acids was found to increase by many folds. The significant increase in level of ascorbic acid (ten times) was observed in green pea tempeh (Table 2). Liem et al., (1977) and Roelofson and Talens (1964) reported that all vitamins had an interesting increased level. The considerable reduction in phytate level was found about 45 to $50 \%$ in green peas. It was noticed the same in soybeans (Table 2). This reduction in phytate content might be due to increased phytase activity.

Sundaramji and Markakis (1977) and Wang, et al., (1980) studied the phytate and phytase of soybeans tempeh. Soybeans were fermented into tempeh by $R$. oligosporus. During this tempeh fermentation the phytic acid content of soybeans was reduced by about $1 / 3$ as a result an equivalent amount of phosphate was released in tempeh. The reduction of phytate was due to phytase liberated by moulds. It was revealed that amount of reducing sugar was increased than the originally present in the substrate. From the Table 2, it observed that tempeh prepared by mould strain of $R$. stolonifer produced the higher reducing sugar as compared to rest of the mould strains. Sucrose content in tempeh prepared from green peas was reduced significantly. The decreased level of sucrose in the tempeh fermented by mould strains $R$. oligosporus and $R$. formosaensis was found to be 25 to $30 \%$ less. Mould strain $R$. stolonifer showed higher effect on reduction in sucrose content in tempeh prepared from green peas (Table 2). This might be due to utilization of sucrose by the moulds for their growth. Recent reports suggest that tempeh contains a wealth of nutrients that are tied to an impressive array of health benefits, including decreased risk of heart disease and strokes, osteoporosis, cancer and digestive disorders, losing excess weight in addition to easing some of the symptoms of menopause (Babu et al., 2009).

\section{Conclusion}

Tempeh like products can be prepared from green peas by the use of mold strains. It is similar in appearance and nutritive value as that of soybean tempeh. The product prepared from different mould cultures was analyzed for proteins, free amino acids, sucrose, reducing sugars, phytate and ascorbic acids. It was observed that proteins, free amino acids, reducing sugar and ascorbic acid were increased considerably than unfermented beans whereas the sucrose and phytate contents were reduced.

It can be concluded that nutritionally better, cheaper fermented products can be made available. It may get popular in general public without forcing to change their dietary habit. It can also help to mitigate the protein deficiency.

\section{References}

1. AOAC (2000). Official methods of analysis of AOAC International (17th ed.). Gaitherburg.USA: AOAC International Inc.

2. Astuti, M., Meliala, A., Dalais, F.S., and Wahlqvist, M.L. (2000). Tempe, a nutritious and healthy food from Indonesia. Asia Pacific Journal of Clinical Nutrition, 9(4): 322-325. 
3. Babu, P.D., Bhakyaraj, R., and Vidhyalakshmi, R. (2009). A low cost nutritious food "Tempeh"-a review. World Journal Dairy \& Food Science, 4(1): 22-27.

4. Berg, S., Olsson, J., Swan berg, M., Schnauzer, J. and Eriksson, A. (2001). Method for the production of fermented cereal food products and products thereof. In World Intellectual Property Organization. Sweden: Olligon AB.

5. Gandjar, I. (1981). Soybean fermentation in Indonesia. The 6th international fermentation symposium. pp. 531-534.

6. Hachmeister, K.A. and Fung, D.Y. (1993). Tempeh: A mold-modified indigenous fermented food made from soybeans and/or cereal grains. Critical Reviews in Microbiology, 19(3): 137188.

7. Hesseltine, C.W. (1965). A millennium of fungi, food, and fermentation. Mycologia, 57(2): 149-197.

8. Hesseltine, C.W., and Wang, H.L. (1980). The importance of traditional fermented foods. BioScience, 30(6): 402-404.

9. Jha, K. and Verma, J. (1980). Removal of flatulence principles from legumes by mold fermentation. Indian Journal of Experimental Biology, 18: 658-659.

10. Ko Swan, D. and Hesseltine, C.W. (1979). Tempe and related foods. Economic Microbiology, 4: 115-140.

11. Liem, I.T., Steinkraus, K.H., and Cronk, T.C. (1977). Production of vitamin B-12 in tempeh, a fermented soybean food. Applied and environmental Microbiology, 34 (6): 773-776.

12. Matsuo, M. (1990). Suitability of 'okara tempe' as foodstuff. Nippon Nogeikagaku Kaishi, 64: 1235-1236.

13. Mugula, J.K. (1992). Evaluation of the nutritive value of maize-soybean Tempe as a potential Weaning food in
Tanzania. International Journal of Food Sciences and Nutrition, 43: 113-119.

14. Murata, K., Ikehata, H. and Miyamoto, T. (1967). Studies on the nutritional value of tempeh. Journal of Food Science, 32(5): 580-586.

15. Nout, M.J.R., and Kiers, J.L. (2005). Tempe fermentation, innovation and functionality: update into the third millennium. Journal of Applied Microbiology, 98 (4): 789-805.

16. Nout, M.J.R., and Rombouts, F.M. (1990). Recent developments in tempe research. Journal of Applied Bacteriology, 69(5): 609-633.

17. Nowak, J. and Szebiotko, K. (1992). Some biochemical changes during soybean and pea tempeh fermentation. Food microbiology, 9(1): 37-43.

18. Padamja, G. and Geroge, M. (2004). Oriental Fermented Food. In: Joshi, V.K. and Pandey, A. (eds.), Biotechnology: Food Fermentation. Asiatech, pp. 538-541.

19. Roelofsen, P.A. and Talens, S.A. (1964). Changes in some B vitamins during molding of soybeans by Rhizopus oryzae in the production of tempeh kedelee. Journal of Food Science, 29(2):224-226.

20. Shurtleff, W. and Aoyagi, A. (2001). The Book of Tempeh, $2^{\text {nd }}$ edition. Pp. 48-50, 103-113.

21. Steinkraus, K.H., Hwa, Y.B., Van Buren, J.P., Provvidenti, M.I. and Hand, D.B. (1961). Proc. cont. Soybean products for Protein in Human Foods. USDA, ARS-71-22.

22. Steinkraus, K.H., Lee, C.Y. and Buck, P.A. (1965). Soybean fermentation by ontjom mold Neurospora. Food Technology, 19(8): 1301.

23. Stillings, B.R. and Hackler, L.R. (1965). Amino acid studies on the effect of fermentation time and heat-processing 
of tempeh. Journal of Food Science, 30(6): 1043-1048.

24. Sudarmadji, S. and Markakis, P. (1977). The phytate and phytase of soybean tempeh. Journal of the Science of Food and Agriculture, 28(4): 381-383.

25. Varzakas, T. (1998). Rhizopus oligosporus mycelia penetration and enzyme diffusion in soybean Tempe. Process Biochemistry, 33: 741-747.

26. Wang, H.L., Ruttle, D.I. and Hesseltine, C.W. (1969). Antibacterial compound from a soybean product fermented by Rhizopus oligosporus. Experimental Biology and Medicine, 131(2): 579-583.

27. Wang, H.L., Swain, E.W. and Hesseltine, C.W. (1980). Phytase of molds used in oriental food fermentation. Journal of Food Science, 45(5), 1262-1266. 